\title{
Recombinant Human Erythropoietin for the Treatment of Anemia in Children With Solid Malignant Tumors
}

\author{
Pedro León, MD,* Miguel Jiménez, MD, Pascual Barona, MD, and \\ Luis Sierrasesúmaga, PhD, FRCP
}

Department of Pediatric Oncology, Clínica Universitaria, School of Medicine, University of Navarra, Pamplona, Spain

\section{Background}

Cancer is often associated with chronic anemia which frequently requires

blood transfusions. This study was performed to assess the efficacy and safety of $r$ HuEPO therapy in children with cancer.

\section{Patients and methods}

Twenty-five patients under 18 years of age with solid malignant tumors were treated with $150 \mathrm{U} / \mathrm{kg} /$ day of r-HuEPO 5 times weekly for 12 weeks. Response was defined as an increase of the baseline hemoglobin level by at least $2 \mathrm{~g} / \mathrm{dl}$. r-HuEPO patients were compared to 25 matched historical controls.

\section{Results}

Response was achieved in $72 \%$ of r-HuEPO patients. Hemoglobin level increased from $9.8 \pm 0.6 \mathrm{~g} / \mathrm{dl}$ at baseline to $12.4 \pm 1.7 \mathrm{~g} / \mathrm{dl}$ at the end of treatment in the $\mathrm{r}-\mathrm{HuEPO}$ group and increased from $9.5 \pm 0.7 \mathrm{~g} / \mathrm{dl}$ to $9.6 \pm 1.4 \mathrm{~g} / \mathrm{dl}$ in the control group $(\mathrm{P}<.001$, Student's t-test). Only $16 \%$ of patients receiving r-HuEPO required blood transfusions vs $96 \%$ of control patients $(\mathrm{P}<.001$, Student's t-test), with mean units of blood transfused per patient being 0.35 in the r-HuEPO group and 3.56 in controls $(\mathrm{P}<.001$, Student's t-test). There was a statistically significance improvement in Karnofsky's index in r-HuEPO patients. No adverse reaction related to r-HuEPO therapy was observed.

\section{Conclusions}

$\mathrm{r}-\mathrm{HuEPO}$ is a safe and effective means of increasing hemoglobin level and reducing blood requirements in children with solid malignant tumors receiving chemotherapy.

\section{Key words}

Recombinant human erythropoietin; anemia, cancer; chemotherapy; children.

*Correspondence to: Pedro León-Molinari, Department of Pediatrics, Clínica Universitaria, Avda. Pío XII, 36, 31008 Pamplona, Spain. 


\section{INTRODUCTION}

Anemia is commonly observed in cancer patients before any myelosuppressive therapy is administered, and may be multifactorial in origin [1]. Nutritional deficiencies, chemotherapy, radiation, bone marrow infiltration, hemorrhages, sequestration in an enlarged spleen, or hemolysis may cause anemia [2], but anemia of chronic disease probably plays the fundamental role in most anemic cancer patients $[3,4]$ with an inadequate erythropoietin (EPO) response to the degree of anemia [5].

Cancer patients with symptoms of anemia frequently require red cell transfusions [6], which carry significant risks in up to $20 \%$ of cases [7-10]. Since recombinant human erythropoietin (r-HuEPO) became available, it has been safely and successfully used in anemic patients with renal disease [11], in AIDS patients treated with zidovudine [12], after bone marrow transplantation [13], for rheumatoid arthritis [14], and for chemotherapy-induced anemia in adult cancer patients $[15,16]$. We report a pilot study to evaluate the clinical utility of r-HuEPO as an alternative to blood transfusion for anemia in pediatric cancer patients receiving chemotherapy.

\section{PATIENTS AND METHODS}

The trial was an open-label, single-institution, pilot study of safety and efficacy. The protocol was approved by the Ethics Committee of our hospital and written informed consent was obtained from at least one parent or a legal representative of all patients.

\section{Patients and Historical Controls}

The study concerns patients under 18 years of age with a diagnosis of solid malignancy confirmed by biopsy specimen, who received cyclic combination chemotherapy for a total of at least 5 days every 3-4 weeks. Prior to study all patients had a life expectancy of at least 3 months, and had been clinically stable for at least 1 month. Laboratory values for inclusion were as follows: hemoglobin $(\mathrm{Hb})$ concentration $<10.5 \mathrm{~g} / \mathrm{dl}$, absolute neutrophil count $\left(\right.$ ANC) $>0.5 \times 10^{3}$ cells $/ \mu 1$, platelet count $>75 \times 10^{3}$ cells $/ \mu 1$, reticulocyte count $<3 \%$, creatinine concentration $<2.0 \mathrm{mg} / \mathrm{dl}$, serum calcium level $<12.0 \mathrm{mg} / \mathrm{dl}$, serum folate, vitamin $\mathrm{B}_{12}$, AST, ALT, bilirubin, and urine analysis within normal limits, ferritin $>30 \mathrm{ng} / \mathrm{ml}$, transferrin saturation $>15 \%$, negative Coombs' test and stool negative for occult blood. Exclusion criteria were: known cerebral metastases, uncontrolled hypertension, seizures, causes of anemia other than chronic neoplastic disease (such as folate and vitamin B12 deficiency, iron deficiency, gastrointestinal bleeding, hemolysis, ...), acute illness within 7 days of study entry, experimental therapy or surgical treatment within 30 days of study entry.

Patients were compared to matched historical controls. Protocols of chemotherapy were continued and unmodified during the study. Standard clinical practices and chemotherapy protocols were similar in both groups. 


\section{Treatment Regimen}

The r-HuEPO was supplied by Boehringer Mannheim, Barcelona, Spain, and administered subcutaneously in a dose of $150 \mathrm{U} / \mathrm{kg} /$ day 5 times weekly for 12 consecutive weeks. Oral iron supplements were commenced if serum ferritin fell to $<100 \mathrm{ng} / \mathrm{ml}$ and/or transferrin saturation fell to $<20 \%$.

\section{Clinical and Laboratory Monitoring}

Medical history and physical examination, a complete blood cell count, reticulocyte count, determinations of serum iron, ferritin, transferrin saturation, folate, vitamin $\mathrm{B}_{12}$, electrolytes, glucose, ALT, AST, bilirubin, performance status according to Karnofsky's index [17], and blood transfusion information were recorded at baseline, every 3-4 weeks (chemotherapy cycle), and at the end of study. Baseline assessments also included 12-lead electrocardiogram, chest x-rays, urinalysis, test of stool for occult blood, and serum EPO level measured by radioimmunoassay (Diagnostic Systems Laboratories, Texas, USA). To define EPO levels as appropriate or inappropriate for a given degree of anemia, the observed/ predicted $\log$ (serum EPO) ratio (O/P ratio) was calculated [18]. The predictive value of EPO for a given degree of anemia was determined by a regression equation obtained by Beguin et al. [19] from reference subjects. During r-HuEPO therapy, weekly assessment of blood pressure and pulse and respiratory rates were performed.

\section{Transfusion Practice and Intensity of Chemotherapy}

Red cell transfusions were performed if $\mathrm{Hb}$ level fell to $<9 \mathrm{~g} / \mathrm{dl}$ and/or symptoms of anemia were developed. The transfusion trigger was determined in both r-HuEPO and control groups to ensure that results were not influenced by differential transfusion practice. The $\mathrm{Hb}$ threshold of $9 \mathrm{~g} / \mathrm{dl}$ might be regarded as relatively high for blood transfusion. However, this trigger was chosen because ours is a reference department for Pediatric Oncology and most of the patients live far from the hospital with an average distance of 350 kilometers. Therefore, an urgent treatment of anemia cannot be undergone when patients are between hospitalization periods.

The intensity of chemotherapy was measured in order to account for the possible effects on our results of differences in intensity between the r-HuEPO and control group. Since the patients received a wide variety of different chemotherapy regimens, a surrogate marker for the intensity of chemotherapy was used. The most appropriate marker appeared to be the effect of chemotherapy on neutrophil and platelet counts. Therefore, the determinations included the number of episodes in which ANC fell to $<1000$ or $<500$ cells/ml and platelet count fell to $<50000$ or 20000 cells $/ \mathrm{ml}(15)$.

\section{Response Criteria}

"Response" was defined as an increase of $\mathrm{Hb}$ of at least $2 \mathrm{~g} / \mathrm{dl}$ with respect to the baseline level within 12 weeks without red cell transfusions [20,21]. 


\section{Evaluation of Toxic Effects}

Any abnormal vital signs or clinically significant abnormal laboratory findings were recorded for consideration as toxic effect.

\section{Statistical Evaluation}

Statistical inference for dichotomous variables formulated as $2 \times 2$ tables was carried out using Fischer's Exact Test. Analysis of variance was used to compare repetitive measurements. Two-sample $t$-tests were used to compare means between groups, and paired $t$-tests were used to test changes from baseline to other values. All statistical tests of hypotheses were two-sided and were carried out at the $\alpha=0.05$ level.

\section{RESULTS}

\section{Demographic and Baseline Characteristics}

A total of 25 patients were enrolled into the study between February 1994 and May 1995 and received r-HuEPO therapy. All of them completed the 12 weeks of treatment. The historical control group included 25 patients treated in our department between September 1992 and January 1994. The demographic and baseline characteristics of both groups are listed in Table I. There were no statistically significant differences between groups for these data.

\section{Hematologic Measurements}

The kinetics of $\mathrm{Hb}$ levels are shown in Figure 1a. Baseline mean $\pm \mathrm{SD} \mathrm{Hb}$ level was similar $(\mathrm{P}=.80)$ in both groups: $9.8 \pm 0.6 \mathrm{~g} / \mathrm{dl}$ in $\mathrm{r}-\mathrm{HuEPO}$ group and $9.5 \pm 0.7 \mathrm{~g} / \mathrm{dl}$ in controls. The $\mathrm{Hb}$ level of r-HuEPO group increased relative to the control group and this increase was statistically significant by week $6(11.9 \pm 2.2$ vs. $10.4 \pm 1.2 \mathrm{~g} / \mathrm{dl} ; \mathrm{P}=$ $.023)$, at week $9(11.7 \pm 2.1$ vs. $10.2 \pm 1.3 \mathrm{~g} / \mathrm{dl} ; \mathrm{P}=.039)$ and at the end of therapy (12.4 \pm 1.7 vs. $9.6 \pm 1.4 \mathrm{~g} / \mathrm{dl} ; \mathrm{P}<.001)$. No relationship was observed between $\mathrm{Hb}$ level and type of tumor nor the presence of bone marrow metastases. There were no statistically significant differences in response to $\mathrm{r}-\mathrm{HuEPO}$ as a function of the severity of the anemia.

In the r-HuEPO group the median absolute reticulocyte count increased from $60000 / \mu 1$ (baseline value) to $126296 / \mu 1$ at week $6(\mathrm{P}=.011), 156185 / \mu 1$ at week $10(\mathrm{P}=.003)$, and $134678 / \mu 1$ at the end of study $(\mathrm{P}=.007)$. There were no significant differences between groups regarding mean corpuscular volume, mean corpuscular $\mathrm{Hb}$, mean corpuscular $\mathrm{Hb}$ concentration, white blood count, and platelets. 


\section{Serum EPO Levels}

Mean serum EPO level was $42.6 \mathrm{mU} / \mathrm{ml}$ (range: 7.8 - 134.4) at baseline in the r-HuEPO group. Endogenous EPO production, measured by $\mathrm{O} / \mathrm{P}$ ratio, was appropriate for the degree of anemia in only 3 patients (Table I). No data on EPO were available in the control group.

\section{Intensity of Chemotherapy}

Intensity of chemotherapy (as measured by neutrophil and platelet counts) for $\mathrm{r}-\mathrm{HuEPO}$ and control patients was not significantly different $(\mathrm{P}>.05)$ (Table I).

\section{Transfusion Requirements}

The percentages of patients transfused before entry into the study were $80 \%$ in the $\mathrm{r}$ HuEPO group and $84 \%$ in the control group (Figure $2 \mathrm{a}$ ), the mean number of units of blood per patient being 2.3 (range: $0-10$ ) and 2.5 (range: $0-7$ ), respectively (Figure $2 b$ ). These differences at baseline were not statistically significant. During the study, the percentages of patients requiring blood transfusion were $16 \%$ (4 out of 25 ) in the $r$ HuEPO group and 96\% (24 out of 25) in the control group (Figure 2a), the mean number of units of blood transfused per patient being 0.35 (range: $0-4$ ) and 3.56 (range: $0-8$ ), respectively (Figure $2 b$ ). These differences between the groups were statistically significant $(\mathrm{P}<.001)$. The mean $\mathrm{Hb}$ level at which patient were given transfusions was $8.8 \mathrm{~g} / \mathrm{dl}$ in $\mathrm{r}-\mathrm{HuEPO}$ group and $8.9 \mathrm{~g} / \mathrm{dl}$ in controls $(\mathrm{P}>.05)$.

\section{Response}

In the r-HuEPO group, 18 patients responded by increases of at least $2 \mathrm{~g} / \mathrm{dl}$ in $\mathrm{Hb}$ level, without requiring blood transfusion. Most responders achieved the necessary increase in $\mathrm{Hb}$ level between the fourth and eighth weeks of therapy.

\section{Karnofsky's Index}

The mean baseline values of Karnofsky's index were $70.8 \%$ in r-HuEPO group and $71.2 \%$ in controls $(\mathrm{P}>.05)$. In the $\mathrm{r}-\mathrm{HuEPO}$ group there was a statistically significant improvement $(\mathrm{P}<.05)$ in Karnofsky's index between the start and the end of the study (Figure 1b). No such improvement was seen in the control group. Of the $15 \mathrm{r}$-HuEPO patients whose Karnofsky's index improved, 13 were responders and 2 were nonresponders.

\section{Iron Parameters}

Serum ferritin level was high at baseline in the r-HuEPO group (probably due to pretransfusions) (307 ng/ ml; range: $25-1200)$. Changes in serum ferritin concentrations during the study fell to reach the limit of statistical significance at week $3(\mathrm{P}=.028)$ and 
week $6(\mathrm{P}=.049)$, increasing after weeks 9 and 12 , but with no statistical significance $(\mathrm{P}>.05)$. Transferrin saturation followed a parallel evolution during the study. Fourteen $(56 \%)$ patients in $\mathrm{r}-\mathrm{HuEPO}$ group required iron supple-mentation during a mean time of 7.2 weeks (range: $3-12$ ).

\section{Safety}

Treatment was well tolerated. No patient was removed from the study because of $r$ HuEPO-related toxicity. No severe adverse effect was reported.

\section{Other Effects}

No statistical differences between the groups regarding electrolytes, serum creatinine, glucose, bilirubin, AST, and ALT were observed.

\section{DISCUSSION}

Anemia is common in cancer patients and red blood cell transfusions are often required. Transfusions are still associated with some adverse reactions and another problem may be represented by religious beliefs. Although the mechanism of cancer-related anemia is not well known, it appears that an inadequated EPO response plays a fundamental role [5]. Recently, some studies have been performed using r-HuEPO to treat anemia in adult cancer patients $[15,16,21,22]$. To confirm and extend the outcome of these results, we performed this pilot study in pediatric cancer patients.

The present study demonstrates that $\mathrm{r}-\mathrm{HuEPO}$ increases the $\mathrm{Hb}$ level in pediatric cancer patients receiving chemotherapy. The increase in $\mathrm{Hb}$ concentration from baseline to the end of study was greater in r-HuEPO treated patients than in controls. This result is in accordance with those reported in the literature [15,16,20-24]. However, in pediatric patients the published data is controversial. Nenadov Beck et al. [25] conclude that $r$ HuEPO administration was safe but ineffective, probably due to a mechanism of transient primary resistance. On the other hand, similar results to ours have been reported by Locatelli et al. [18] in children with acute leukemia given allogeneic bone marrow transplantation, and by Kronberger et al. [26] in pediatric patients with Ewing's sarcoma and osteosarcoma.

We did not observe any statistically significant correlation between increase in $\mathrm{Hb}$ levels and tumor type in our study, but this is not very indicative, given the limited number of cases of each tumor type and the fact that hematological malignancies were not included. Interestingly, neither tumor type nor bone marrow involvement appeared to influence the response to r-HuEPO therapy [27]. Patients with hematologic and solid tumors respond equally well to r-HuEPO [15].

r-HuEPO has been shown to promote both granulocyte and megakaryocyte colony growth [28,29]. In our study, as in others [18,22], there were no significant differences between the r-HuEPO group and control group in either white blood cell or platelet counts. 
The transfusion history of the patients was almost identical in the r-HuEPO and control groups, but subsequent to the improvement in $\mathrm{Hb}$ levels in $\mathrm{r}-\mathrm{HuEPO}$ treated patients there was a reduction in the transfusion requirements of this group. This reduction is consistent with the findings of other authors [16,18,21,30,31]. Abels [15] observes that transfusion rates were reduced after 1 month of r-HuEPO therapy, suggesting that this lag in response was probably related to the time required for the stimulation of erythropoiesis to be reflected in decreased transfusion practice.

Response was achieved in $72 \%$ of r-HuEPO patients. Tumor type and bone marrow involvement did not appear to influence the response rate. This response percentage is not associated with differential transfusion practice between groups, nor with a differential intensity of chemotherapy. The response rates in published studies are in accordance with our findings, and range from $31.7 \%$ [15] to $82-85 \%$ [16,32], reflecting differences in dose, route of administration, duration of therapy, the response criteria used, and the patient population under study [27].

Although most patients in this study had a favorable Karnofsky's index at baseline, the r-HuEPO patients achieved a statistically significant improvement of their scores from the third week of treatment. This observed improvement is in accordance with reports on the effect of r-HuEPO therapy in patients with end-stage renal disease [33], and in adult cancer patients $[15,21,31,34]$. Improvements in quality of life of patients with response to therapy may be explained by the clinically observable subsiding of all or most symptoms of anemia [34]. Even two patients with no response to r-HuEPO treatment had some significant improvement during therapy, as reported by Leitgeb et al. [34] and Ludwig et al. [21], probably due to placebo effect or marginal beneficial effects of the treatment.

In accordance with other reports [16,21,25], r-HuEPO treatment was excellently tolerated by all patients, causing no severe adverse reaction. No patient complained of the local burning sensation at the site of injection primarily related to epoetin- $\alpha$ administration. Although hypertension in cancer patients receiving r-HuEPO has been reported [22], it is less frequent and of easier management than in renal patients [11].

\section{CONCLUSIONS}

This study demonstrates that r-HuEPO therapy is a safe and effective means of increasing $\mathrm{Hb}$ level and reducing blood requirements in pediatric patients with malignant solid tumors receiving chemotherapy.

On the basis of this data, we suggest that more extensive trials in pediatric cancer patients should be embarked upon in order to clarify the effect on transfusion requirements, to define the optimal dose and to identify prediction factors for response to $\mathrm{r}-\mathrm{HuEPO}$ therapy. 


\section{ACKNOWLEDGMENTS}

We thank Xavier Llobet, MD, and Antonio Mayol, MD, from Boehringer Mannheim, Barcelona, for providing us the r-HuEPO and support for the study and to David Burdon for the grammar revision of the manuscript.

\section{REFERENCES}

1. Henry DH: Clinical application of recombinant erythropoietin in anemic cancer patients. Hematol Oncol Clin North Am 8:961-973, 1994.

2. Duhrsen U, Hosseld DK: Hematopoietic growth factors and the treatment of tumor-associated anemias. Ann Hematol 69:213-221, 1994.

3. Zucker S: Anemia in cancer. Cancer Invest 3:249-260, 1985.

4. Steinberg D: Anemia and cancer. CA Cancer J Clin 39:296-304, 1989.

5. Miller CB, Jones RJ, Piantadosi S, Abeloff MD, Spivak JL: Decreased erythropoietin response in patients with the anemia of cancer. N Engl J Med 322:1689-1692, 1990.

6. Skillings J, Sridhar F, Wong C, Paddock L: The frequency of red cell transfusion for anemia in patients receiving chemotherapy. A retrospective cohort study. Am J Clin Oncol 16:22-25, 1993.

7. Walker RH: Special report: Transfusion risk. Am J Clin Pathol 88:374-378, 1987.

8. Klein HG: Immunologic aspects of blood transfusion. Semin Oncol 21 (suppl 3): 16-20, 1994.

9. $\quad$ Dodd RY: The risk of transfusion-transmitted infection. N Engl J Med 327:419420, 1992.

10. Lackritz EM, Satten GA, Aberle-Grasse J, Dodd RY, Raimondi VP, Janssen RS, Lewis F, Notari EP, Petersen LR: Estimated risk of transmission of the human immunodeficiency virus by screened blood in the United States. N Engl J Med 333:1721-1725, 1995.

11. Eschbach JW, Egrie JC, Downing MR, Browne JK, Adamson JW: Correlation of anemia of end-stage renal disease with recombinant human erythropoietin. $\mathrm{N}$ Engl J Med 316:73-78, 1987.

12. Fischl M, Galpin J, Levine J, Groopman JE, Henry DH, Kennedy P, Miles S, Robbins W, Starrett B, Zalusky A, Abels RI, Tsai HC, Rudnick SA: Recombinant human erythropoietin for patients with AIDS treated with zidovudine. N Engl J Med 322:1488-1493, 1990.

13. Klaesson S, Ringden O, Ljungman P, Lonnqvist B, Wennberg L: Reduced blood transfusion requirements after allogeneic bone marrow transplantation: results of a randomized, double-blind study with high-dose erythropoietin. Bone Marrow Transplant 13: 397-402, 1994.

14. Murphy EA, Bell AL, Wojtulewski J, Brzeski M, Madhok R, Capell HA: Study of erythropoietin in treatment of anemia in patients with rheumatoid arthritis. $\mathrm{Br}$ Med J 30:1337-1338, 1994.

15. Abels R: Erythropoietin for anaemia in cancer patients. Eur J Cancer 29A (suppl 2):S2-S8, 1993.

16. Cascinu S, Fedeli A, Del Ferro E, Catalano G: Recombinant human erythropoietin treatment in cisplatin-associated anemia: a randomized, doubleblind trial with placebo. J Clin Oncol 12: 1058-1062, 1994. 
17. Karnofsky DA, Abelmann WH, Kraver LF: The use of nitrogen mustards in the palliative treatment of carcinoma with particular reference to bronchogenic carcinoma. Cancer 1:634-669, 1948.

18. Locatelli F, Zecca M, Pedrazzoli P, Prete L, Quaglini S, Comoli P, De Stefano P, Beguin Y, Robustelli della Cuna G, Severi F, Cazzola M: Use of recombinant human erythropoietin after bone marrow transplantation in pediatric patients with acute leukemia: effect on erythroid repopulation in autologous versus allogeneic transplants. Bone Marrow Transplant 13:403-410, 1994.

19. Beguin Y, Yerna M, Loo M, Weber M, Fillet G: Erythropoiesis in multiple myeloma: defective red cell production due to inappropriate erythropoietin production. Br J Haematol 82:648-653, 1992.

20. Ludwig H, Fritz E, Leigeb C, Pecherstorfer M, Samonigg H, Schuster J. Prediction of response to erythropoietin treatment in chronic anemia of cancer. Blood 84:1056-1063, 1994.

21. Ludwig H, Sundal E, Pecherstorfer M, Leitgeg C, Bauernhofer T, Beinhauer A, Samonigg H, Kappeler AW, Fritz E: Recombinant human erythropoietin for the correction of cancer associated anemia with and without cytotoxic chemotherapy. Cancer 76:2319-2329, 1995.

22. Falkson CI, Keren-Rosenberg S, Uys A, Falkson G, Stebens K, Vermaak WJH: Recombinant human erythropoietin in the treatment of cancer-related anaemia. Oncology 51:497-501, 1994.

23. Barlogie B, Beck T: Recombinant human erythropoietin and the anemia of multiple myeloma. Stem Cells 11:88-94, 1993.

24. Cascinu S, Fedeli A, Fedeli SL, Catalano G: Cisplatin-associated anaemia treated with subcutaneous erythropoietin. A pilot study. Br J Cancer 67:156$158,1993$.

25. Nenadov Beck M, Beck D: Recombinant erythropoietin in acute chemotherapyinduced anemia of children with cancer. Med Ped Oncol 25:17-21, 1995.

26. Kronberger M, Keck B, Zoubek A, Neophytou B, Bóck A, Fritsch G, Gadner H, Henry D: Prevention of anemia with r-HuEPO in children with Ewing's sarcoma or osteogenic sarcoma. [Abstract]. Proc ASCO 14:258, 1995.

27. Spivak JL: Recombinant human erythropoietin and the anemia of cancer. Blood 84:997-1004, 1994.

28. Dessypris EN, Graber SE, Krantz SB, Stone WJ: Effects of recombinant erythropoietin on the concentration and cycling status of human marrow hematopoietic progenitor cells in vivo. Blood 72:2060-2065, 1988.

29. Ganser A, Bergmann M, Voelkers B, Gruntzmacher P, Scigalla P, Hoelzer D: In vivo effects of recombinant human erythropoietin on circulating human hematopoietic progenitor cells. Exp Hematol 17:433-435, 1989.

30. Oster W, Herrmann F, Gamm H, Zeile G, Lindeman A, Müller G, Brune T, Kraemer H-P, Mertelsmann R: Erythropoietin for the treatment of anemia of malignancy associated with neoplastic bone marrow infiltration. J Clin Oncol 8:956-962, 1990.

31. Case DC, Bukowski RM, Carey RW, Fishkin EH, Henry DH, Jacobson RJ, Jones SE, Keller AM, Kugler JW, Nichols CR, Salmon SE, Silver RT, Storniolo AM, Wampler GL, Dooley CM, Larholt KM, Nelson RA, Abels RI: Recombinant human erythropoietin therapy for anemic cancer patients on combination chemotherapy. J Natl Cancer Inst 85:801-806, 1993. 
32. Ludwig H, Fritz E, Hotzmann H, Hocker P, Gisslinger H, Barnas U: Erythropoietin treatment of anemia associated with multiple myeloma. N Engl J Med 322:1693-1699, 1990.

33. Levin NW: Quality of life and hematocrit level. Am J Kidney Dis 20(suppl 1):16-20, 1992.

34. Leitgeb C, Pecherstorfer M, Fritz E, Ludwig H: Quality of life in chronic anemia of cancer during treatment with recombinant human erythropoietin. Cancer 73:2535-2542, 1994. 
Table 1. Demographic and Baseline Characteristics

\begin{tabular}{|c|c|c|}
\hline Parameter & r-HuEPO* & Control* \\
\hline Number of patients & 25 & 25 \\
\hline \multicolumn{3}{|l|}{ Sex } \\
\hline Male & 14 & 14 \\
\hline Female & 11 & 11 \\
\hline Mean age, y (range) & $12.6(6-17)$ & $11.8(5-17)$ \\
\hline Mean \pm SD weight $(\mathrm{kg})$ & $49.4 \pm 16.1$ & $44.3 \pm 16.6$ \\
\hline Mean \pm SD height $(\mathrm{cm})$ & $156 \pm 16.1$ & $148.8 \pm 19.6$ \\
\hline Mean \pm SD Hb level (g/dl) & $9.8 \pm 0.6$ & $9.5 \pm 0.7$ \\
\hline Mean \pm SD WBC count $(\times \mu \mathrm{l})$ & $5904 \pm 3170$ & $7517 \pm 3080$ \\
\hline Mean \pm SD platelet count $(\times \mu 1)$ & $256000 \pm 72000$ & $254000 \pm 69000$ \\
\hline Mean serum EPO, mU/ml (range) & $42.6(7.8-134.4)$ & \\
\hline Mean $\mathrm{O} / \mathrm{P}$ ratio (range) & $0.7(0.44-1.08)$ & \\
\hline $\mathrm{O} / \mathrm{P}$ ratio $<1$ ( $\%$ of patients $)$ & 88 & \\
\hline \multicolumn{3}{|l|}{ Tumor type $(\%)$} \\
\hline Ewing's sarcoma & 36 & 40 \\
\hline Ostesarcoma & 32 & 32 \\
\hline CNS tumors & 16 & 16 \\
\hline Hodgkin's lymphoma & 8 & 8 \\
\hline Rhabdomyosarcoma & 4 & 4 \\
\hline Unknown primary site & 4 & \\
\hline $\mathrm{N}$ of episodes with ANC $<1000$ cells $/ \mu 1$ & 14 & 12 \\
\hline $\mathrm{N}$ of episodes with $\mathrm{ANC}<500$ cells $/ \mu 1$ & 20 & 18 \\
\hline $\mathrm{N}$ of episodes with platelets $<50000 / \mu 1$ & 11 & 7 \\
\hline $\mathrm{N}$ of episodes with platelets $<20000 / \mu 1$ & 4 & 5 \\
\hline \multicolumn{3}{|c|}{$\begin{array}{l}\text { *No statistically significant differences }(P>.05) \text { between groups. } \\
\text { y: years; Hb; hemoglobin; WBC: white blood cell; CNS: central nervous system; O/P } \\
\text { ratio: observed/predicted log (serum EPO) ratio; N: number of data; ANC: absolute } \\
\text { neutrophil count. }\end{array}$} \\
\hline
\end{tabular}


(a)

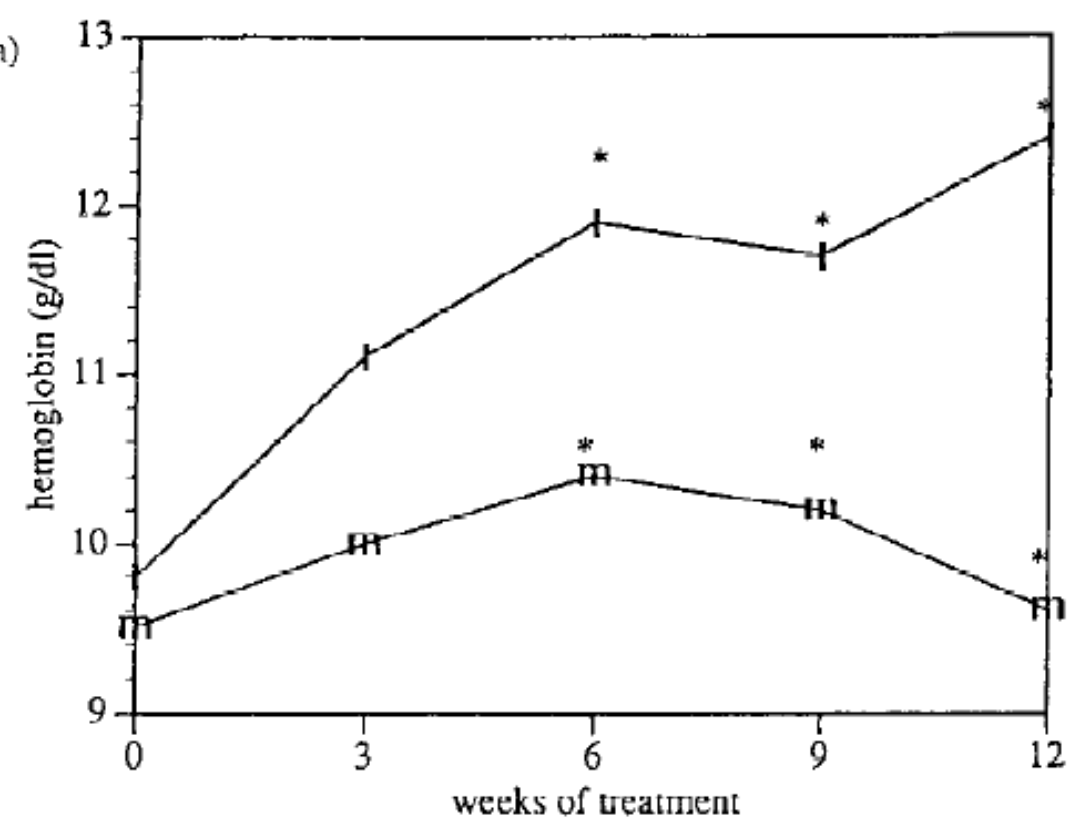

+ I-HuEPO

-m. Control

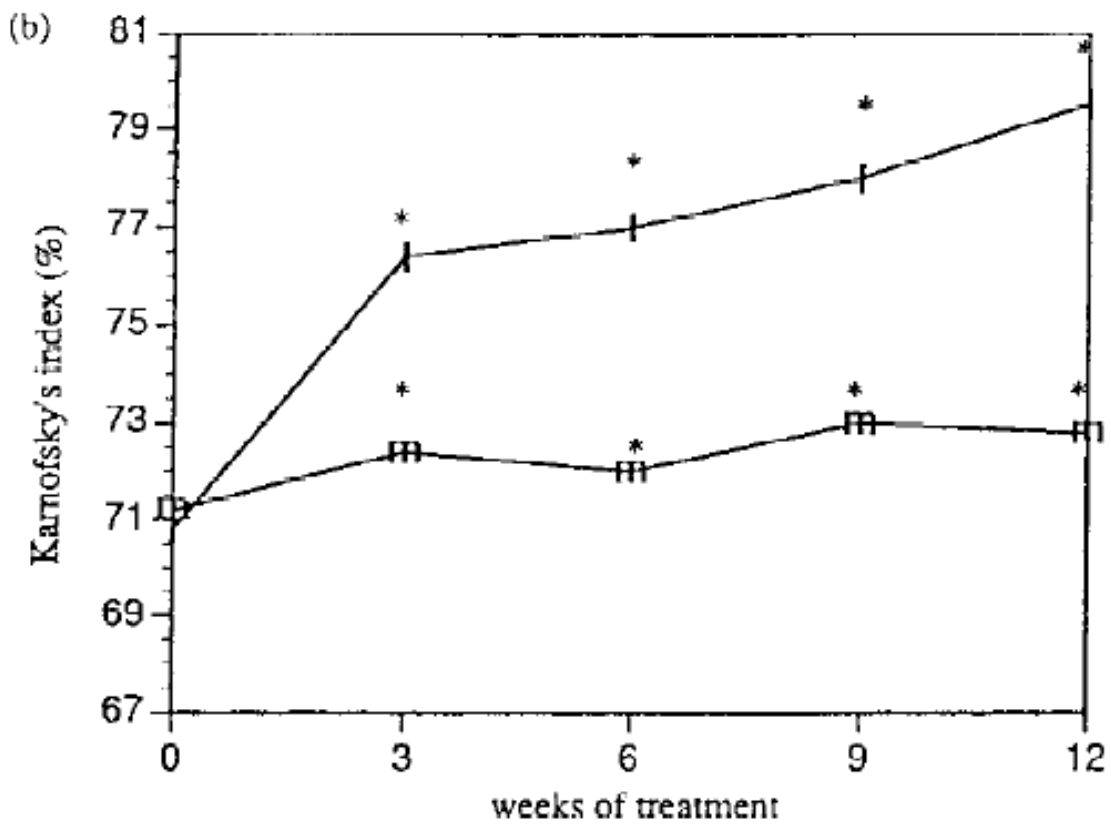

Figure 1. Changes in hemoglobin levels (a) and Karnofsky's index (b) in both groups during study. ${ }^{*} P<.05$, Student's $t$-test. 
(ii)

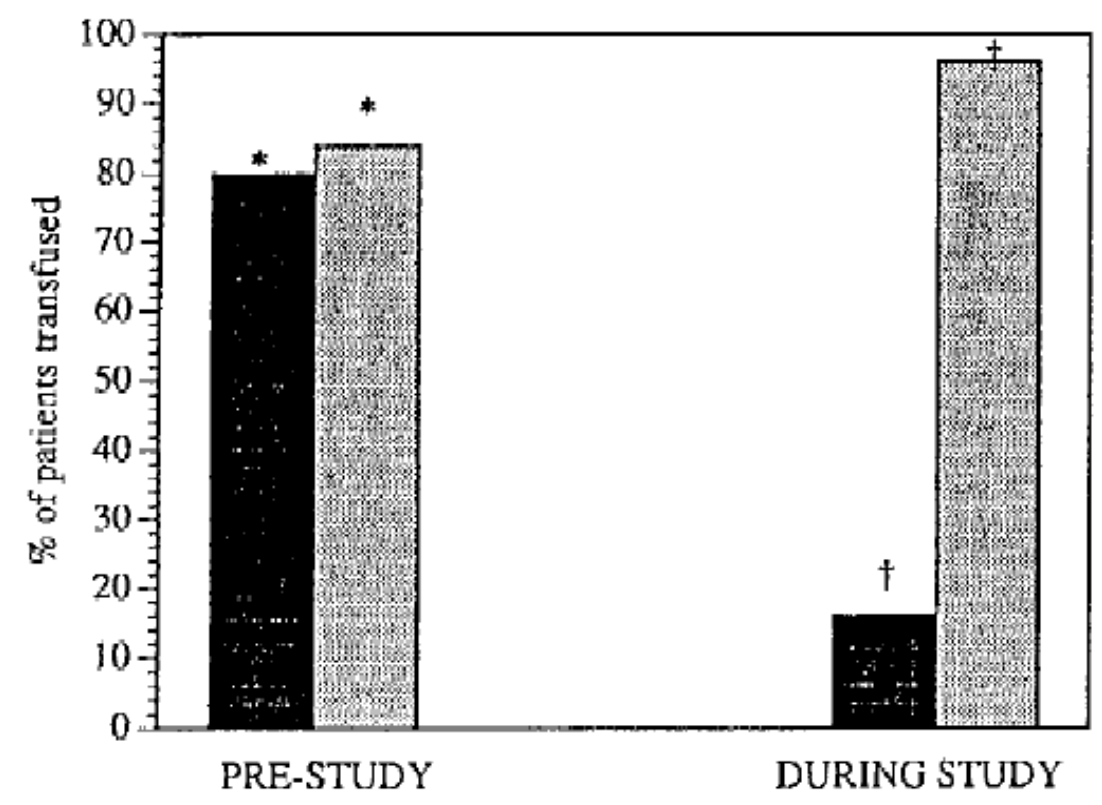

r-HuEPO

Control

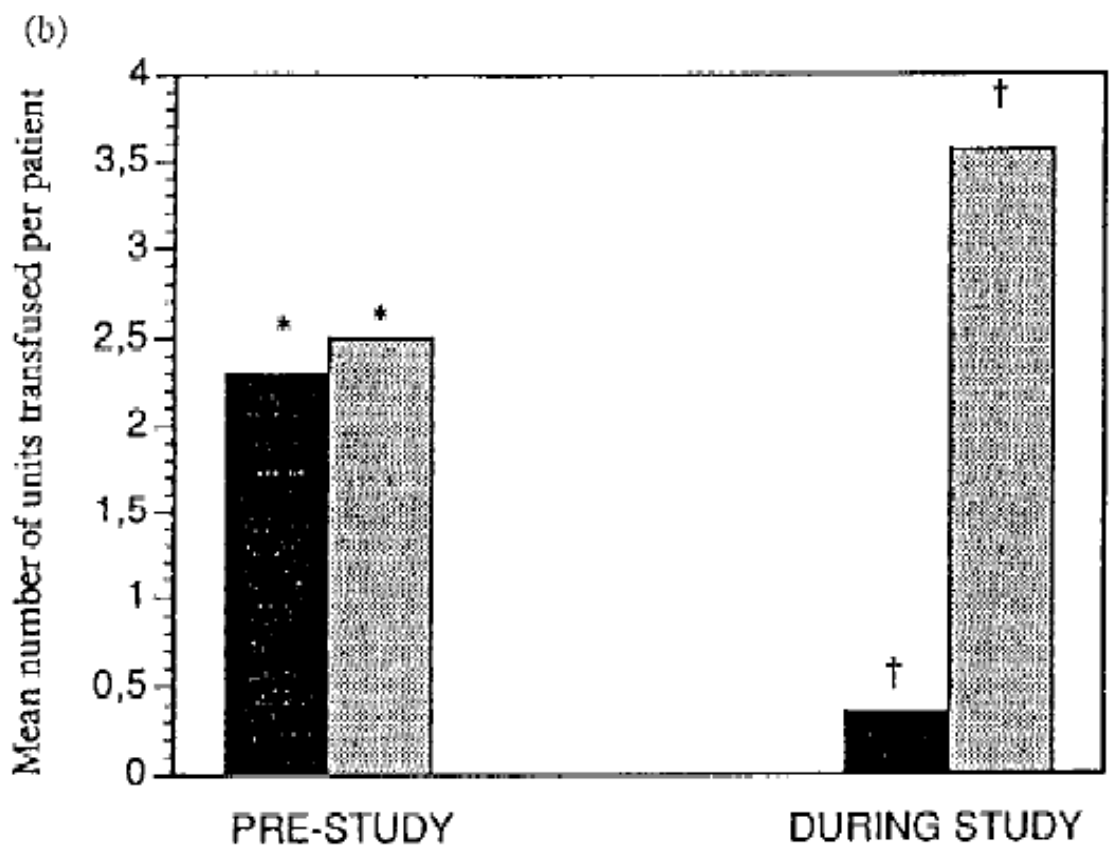

Figure 2. Percentage of patients (a) and mean number of units transfused per patient (b) before (left columns) and during (right columns) study period. ${ }^{*} P>.05 ; \dagger P<.001$, Student's $t$-test. 